\title{
A view on Didactics and Instructional Planning from the Perspective of research on learner development and educational experience
}

Meinert A. Meyer

\section{(2) OpenEdition Journals}

Electronic version

URL: http://journals.openedition.org/educationdidactique/816

DOI: 10.4000/educationdidactique.816

ISBN: 978-2-7535-1624-3

ISSN: $2111-4838$

Publisher

Presses universitaires de Rennes

\section{Printed version}

Date of publication: 1 October 2010

Number of pages: 75-99

ISBN: 978-2-7535-1300-6

ISSN: 1956-3485

\section{Electronic reference}

Meinert A. Meyer, «A view on Didactics and Instructional Planning from the Perspective of research on learner development and educational experience », Éducation et didactique [Online], 4-2 | 2010, Online since 01 April 2012, connection on 10 December 2020. URL : http://journals.openedition.org/ educationdidactique/816; DOI : https://doi.org/10.4000/educationdidactique.816 


\title{
A VIEW ON DIDACTICS AND INSTRUCTIONAL PLANNING FROM THE PERSPECTIVE OF RESEARCH ON LEARNER DEVELOPMENT AND EDUCATIONAL EXPERIENCE
}

\author{
Meinert. A. Meyer, (University of Hamburg)
}

\begin{abstract}
First, the author gives a short description of the current German situation with respect to Educational Research ('empirische Bildungsforschung'), to General Didactics ('Allgemeine Didaktik'), and to Research on Learner Development and Educational Experience ('Bildungsgangforschung') in particular. Then, the didactics for the third field of study, 'Bildungsgangdidaktik', are described, and an example of instructional analysis from this perspective is given: an English class at senior high school (upper secondary stage). The example is of help for one of the central concepts of 'Bildungsgangforschung', the description of authentic student participation. With reference to the example, and going beyond, the developmental task concept is described and defended. Quality criteria for learner development and instructional planning, which are partly based upon empirical data, are proposed. In doing so, particular attention is given to the tension between general education as suggested by Wolfgang Klafki ('Allgemeinbildung), teachers' professional developmental tasks, and students' efforts to achieve the developmental tasks adequate for their age group. A graduated model of instructional cooperation for the description and evaluation of classroom instruction from the point of view of learner development and educational experience is used for a reflective final step.
\end{abstract}

Meinert. A. Meyer

\section{Introduction: Educational Standards and Research on Learner Development and Educational Experience}

Following the results of the PISA study (2001) that shocked German politicians, educators and educational scientists alike, the leading representatives of empirical education research ('Bildungsforschung') initiated a state funded program aiming at the definition of educational standards and competence levels for their assessment (cf. Olaf Köller 2008) and criticized the leading representatives of German general didactics for their neglect of empirical research. This criticism is not new: In the $20^{\text {th }}$ century, the representatives of German general didactics have often been reproached for neglecting empirical research. The PISA shock, however, lead to an unprecedentedly fierce expression of this criticism.

That is why I will try to meet, in my paper, two competing demands: the commitment to empirical research on the one hand, and the objective to offer applicable planning recommendations, on the other. I am aware that this is not an easy task. I base my suggestions for the new focus in general didactics on the empirical findings we could gather in the context of the research conducted by the Hamburg University
PhD Graduate School on 'Bildungsgangforschung'. I was the speaker of this school ${ }^{1}$.

The momentum of the PISA shock prompted the leading representatives of empirical education research ('Bildungsforschung') to initiate a state funded program which attempts at defining educational standards and levels of competence for their assessment. I start with a quotation from this expertise. The authors write in their introduction:

"If we are successful in creating educational standards ('Bildungsstandards') reflecting a sustainable vision of educational processes ('Bildungsprozesse'), a modern philosophy of domains, a developmental perspective for students' competences, these standards may well become a motor for the educational development of our schools." (Klieme et al., 2003, p. 10, own translation)

I am thrilled! To me, too, outlining a vision of educational processes is of great importance, as are a philosophy of domains, and improved domain specific conditions. Yet, I doubt that standards for themselves can become a motor for educational development. We need a theory of educational processes that does justice to both sides, to our students and to 
society as a whole. We need concepts that combine educational standards with plurality, heterogeneity, and individual development.

I consider it helpful to give a short description of the prevailing trends in the field of didactics in Germany, today (cp. Meyer, Prenzel, Hellekamps, eds., 2008; Terhart 2009). As far as I know, there is overall consensus, that general didactics is concerned with the following themes:

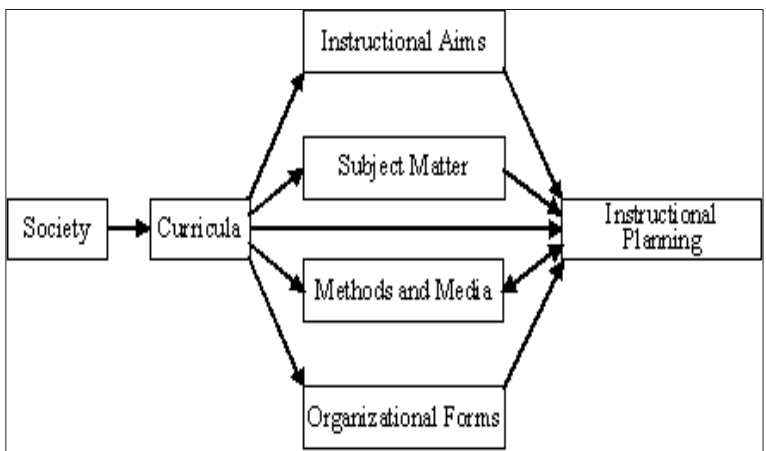

Fig. 1: Traditional determination of themes in general didactics

The scheme identifies the field of general didactics with focus on the instructional process in a traditional way. Within this scheme, educational standards have to be understood as a modern version of the curricula. The scheme allows me to give a formal description of the change of perspective I am interested in. It can be varied as follows:

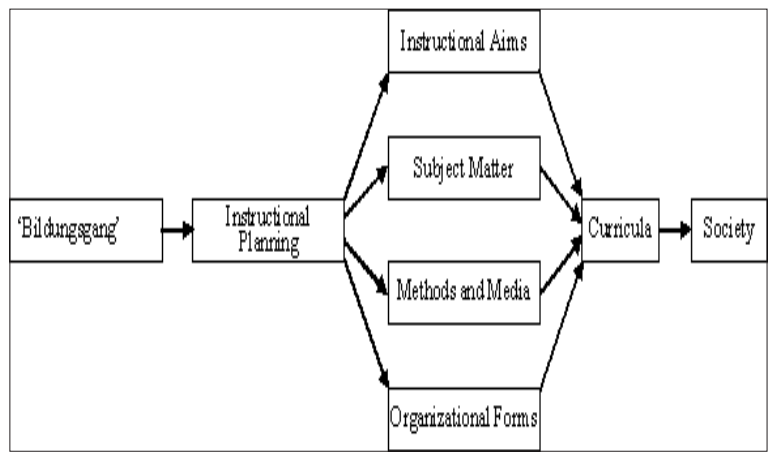

Fig. 2: Themes in general didactics from the perspective of learner development and educational experience
At first glance, the change of perspective produces problems: Does it make sense to conceive the instructional planning as a product of the educational careers of the students? Is it legitimate to understand the established fields of instructional planning, teaching aims, subject matter and methods and media as caused by the students' careers and the teachers' instructional planning? Does it make sense to understand the curricula as products of the teachers' teaching aims? In this paper, I will present arguments which are meant to show that it makes sense! And I have experienced teachers at my side. They know very well that curricula, teaching aims, subject matter and methods/ media depend on what they, the teachers, can accomplish in schools, and that their work depends on what the students bring in, i.e. on their biographical background, their educational experience, their learning history, their competences, their interests and expectations concerning the future. In short, turning the instructional thinking as sketched by the first scheme into the opposite direction makes sense ${ }^{2}$

I can now give an outline of my paper. I will first present an example, a little scene from an English class in an 11th grade (upper secondary stage) course, in order to describe an especially difficult phenomenon - authenticity in student participation (section 2). Based on the empirical example, I shall criticize traditional German didactics (section 3), discuss the key idea, the 'developmental task concept', and relate it to general education ('Allgemeinbildung'). The tension between these concepts makes it necessary to describe the teacher role. I claim that teachers and students have to cope with developmental tasks (section 4). Based on this, I propose a list of quality criteria for lesson planning and instruction from the students' point of view (section 5) and then draw a scheme for instructional planning from this perspective (section 6). It makes sense to distinguish three levels of analysis for the further development of general didactics. The first level describes the surface phenomenology of teaching-learning processes: Students normally comply with teachers' demands. The second level deals with the communicative structure of instruction: It describes the teaching-learning process as an activity within a community of practice. The third level then defines an intergenerational dimension of 
schooling and teaching-learning processes: It deals with the mutual acknowledgment of teachers by students and of students by teachers, which allows the students to design their own world view and their own self concepts (section 7 ). ${ }^{3}$

\section{English Instruction in an 11th Grade Advanced Level Course}

Basing my argumentation on a case study, I will now put both the established research on instruction and the published instructional planning models into perspective; I will do so from the angle of didactics for learner development and educational experience ('Bildungsgangdidadaktik'). ${ }^{4}$

Students and teachers talking at cross-purposes is not a new finding in instructional research. However, in our study on student participation funded by the German Research Association we, Meinert Meyer, Ingrid Kunze, and Matthias Trautmann, frequently observed that instruction went on smoothly, notwithstanding that students and teacher were talking at cross-purposes, and this was new to us! Instruction does not come to a standstill just because teacher and students do not understand each other! Rather, the agents construct their own worlds and find their own sense in what is going on!

The example I give is taken from an English lesson in an eleventh grade advanced level course (Upper Secondary Stage, Gymnasium), where the teacher, who due to technical problems is not able to perform his initially planned program, improvises and assigns the task to describe "the ideal teacher" to his students. While the students are very interested in working out what it is exactly that constitutes an ideal teacher, their teacher, Mr. Quandt, is primarily interested in vocabulary training, this, however, being only the first level of perception and evaluation of the setting.

I can illustrate the contradictory perspectives on the topic - the ideal teacher - and the teacher-student interaction depending on it, with short passages from both the two interviews we did with Mr. Quandt and from a discussion with his students. The points Mr. Quandt puts forth in the interviews reveal a Prussian commitment to hard work and its rewards, whereas the students rather demand for themselves a postcommunist - so to speak - event- and fun perspective. What results is a clash of non-identical educational intentions and strategies.

Mr. Quandt tells us in the first interview that he had been a diligent student in his time and that it is therefore difficult for him to accept his students' attitude: "I cannot understand when students have time to go shopping in the afternoon. When I came home from school I had about an hour to get something to eat, some time to read and to relax. But then it was already time to actually sit down and study for school. I sat each day for three hours at least. Sometimes it was just for an hour, but then, the other days it had to be more. So, I fear, or am almost certain that students nowadays can't do this anymore." 5 It does not come as a surprise that Mr. Quandt is neither satisfied with the lack of diligence on the part of his students, nor with their low level of communicative competence in English as a foreign language.

He describes his image of good English instruction as follows: "The ideal would be students having a discussion, entirely in English, and they want to have me in it, but not as the one who's in charge but just as someone whose opinion they are also interested in. (...) That'd be my ideal." Next, Mr. Quandt complains about the students' insufficient participation: "That's just it (..) the student says: The teacher will do it, it's his job teaching us, so let him do it then. ${ }^{6 "}$

The students, on the other side, complain about Mr. Quandt's high expectations. In their view he ought to be much more patient with them, he should show some more understanding for the many mistakes they make in class communication and in their examinations. Even though he does show personal interest for his students, as they see it, he is too demanding. A female student: "Uh, I think Mr. Quandt demands of us, uh, to be like ideal students, where actually there's no such thing. We are supposed to achieve, meet his standard wherever possible, well, especially now, uh, concerning vocabulary and so on, uh, I think, uh, let me say it this way: it is not right to confront us with vocabulary from second grade Gymnasium " 7 .

It is obvious that the students refuse the roles Mr. Quandt assigns to them. In their opinion he 
does not acknowledge their performance adequately. Therefore, a discussion in class about the "ideal teacher" to them is a perfect opportunity to present their position by changing the topic: Which are the qualities that would allow them to see Mr. Quandt as an ideal teacher?

One of the students, Oliver, lists the qualities of a good teacher: He should be patient and goodnatured. He should have a calming effect on classroom interaction. He should accept his own faults as well as those of his students. He should show some understanding for the situation his students are in. Oliver: "I think a ideal teacher (= Ah! Be careful! Ein: An! =) an ideal teacher, uh, needs to be patient with the students. (..) (=Mmhmh=) He (...) (teacher writing on chalkboard) he should be, uh, humorous, (.) that's, uh, so the, uh, (.....) so the lessons uh became a bit more, uh, (..) relaxing, uh, relaxed (=Yeah: relaxed $=)$ Uh, (...) he has to be aware of his own faults and he has to accept them and then he have, he has to accept the faults of his students, of course, (.) Uh, (.) he must be in control of the class but not with brutality or, uh, no? (laughs) But - (..) well (...)"

Oliver, in this passage, clearly speaks of the ideal teacher's faults, and claims that teachers should be aware of them. But somehow Mr. Quandt gets to think that it is about mistakes in his and their foreign language production and he even takes it to imply that Oliver does not accept teachers' grading. It does not occur to Mr. Quandt to ask Oliver whether he has gotten him right.

It is hard to say, today, what it was that Oliver had in mind; Mr. Quandt interrupts him. But it becomes obvious that he accepts that the teacher has to assess his students' language performances, something that is very important to Mr. Quandt, who alters the course of argumentation. He speaks of the necessity for teachers to understand their students' mistakes, not of having to accept their faults. He deplores the many mistakes students make in his classes, and he brings in himself and his work as teacher of English: "One question: Uh, you said something about - what was the thing? Before brutality? Yeah. Accept his own mistakes and students $m$-, understand students' mistakes. $(=M m h=)$ And what about writi-, students write tests? (...) And, (..) st-, still you get marks for certain results. And the more mistakes you make, the, the worse your marks are. (.) So I have, me as a teacher, I have to criticize your mistakes and mark it. But you, you wouldn't like that? (...)"

Oliver replies: "Yes. I wouldn't, I wouldn't like it, well, but I would accept it (=good=) but if you would, uh, (...") Oliver cannot complete his sentence; he is once again interrupted by Mr. Quandt: "Well, you said >you should understand students' mistakes<, that's, therefore I asked ( $=U h=)$ Yeah? So I don't understand, very often I don't understand students' mistakes in tests. Because we practice, all the others teacher, the other teachers practice a lot of, that's what I mean, $(=m h=)$, (...), yeah? Uh, (..) you, you also said he should be aware of his own mistakes. Right. Is there a word you can find? (...")

Oliver doesn't protest against the turn Mr. Quandt gives to the course of the discussion. The discussion in class continues. The ideal teacher has to have expert knowledge; therefore he may well criticize and correct the students.

But then, Greta, a fellow student, misleadingly talks of teachers' mistakes, and again, confuses Mr. Quandt. He asks: "You mean his own mistakes? (.) To improve the mistakes. To avoid probably. Mmhmh. Therefore he must be strict? Mmhmh."

Balthasar then raises the question whether ideal teachers are such an attractive idea, at all. There are only real, actual people, no ideal persons. Therefore, there is no such thing as an ideal teacher!

I stop my reconstruction and analysis of this instructional sequence at this point. I have shown that even in a short sequence of round about fifteen minutes many misunderstandings may occur. However, what is really exciting in the analysis of this sequence on a more profound level, is the fact that the students are indirectly communicating with their teacher. They tell Mr. Quandt in many ways how they would like him to be. While he would likely not have accepted this message in direct communication, he accepts it by transforming the theme into vocabulary training.

A group of students turn this into the subject of discussion in their group interview after class. A female student: “(...) Somehow I got sort of ' $n$ 
impression that he tried to make us go like: Yes, (loud laughter) you are the, (in chorus) "the ideal teacher!" Another female student: "He somehow hinted at it at one point $(=$ exactly=) when Nora said: $>$ Well, at our school there's some, who s-, uh, teachers who like come close to being an ideal teacher<. And that's right when I thought now he will ask for sure: $>$ Who are they?< (laughter from the group) but Mr. Quandt could do without that, for sure." Female student: "There you are." A third female student: "He couldn't have asked that." (Laughter from the group) Female student: "That's when ... you sort of could notice, like always give suggestive answers: >Well, there's no such thing < and: >Can't be<. You just tried to sort o' talk round a bit, an' nobody really got to the point."

The students quite skillfully analyze and evaluate the instructional setting organized by Mr. Quandt and shaped by them: The teacher changes the direction of the discussion, they are used to that. He writes down adjectives that may be used to describe the ideal teacher, and thus finds a way to connect to the students. He identifies with the ideal teacher, but the students do not accept that.

This leads to the question whether misunderstandings like the one between Mr. Quandt and his students can be described within the framework of traditional didactic analysis, in an adequate way. I think the answer is "No".

Undoubtedly, there is enough traditional research and didactic theory building where students are attributed an important role in lesson planning, e.g. in Wolfgang Klafki's critical-constructive didactics or in Hilbert Meyer's action-oriented didactics. I'll come back to that in the next section. However, the students are not attributed the role they really have in the instructional process. They are not conceived as acting subjects with 'biographical package' and 'learning history'; instead, they are conceived as the 'objects' of the teachers' activities.

Obviously, the sequence I have presented above gets its liveliness from the fact that the students are involved, that they think about improving Mr. Quandt's lesson planning and his professional behavior. We call such sequences authentic learning situations and examples of authentic student participation.
Authenticity either occurs or does not occur! It is a quality achieved through both sides' willingness to cooperate, teachers' and students' alike. It should be apparent that as a teacher one cannot plan authenticity of teacher/ learner interaction in advance, and this is so because the teachers and the students participate as living beings, as subjects with intentionality; they invest their learner biography and their developmental perspectives. In our example, Mr. Quandt brings in his Prussian commitment to hard work and to correctness, and the students bring in their fun perspective.

The example can be used to illustrate my concept of instructional analysis, which is based on Lothar Klingberg's general didactics. ${ }^{8}$

Klingberg constructs didactics very coherently out of the instructional process and gives systematic thought to the interrelations of teachers and students. From his perspective (and from the perspective of research on learner development and educational experience) the instructional process is an interplay of teachers and students, and this interplay may be characterized both by harmony and promising perspectives, but also by conflicts. Klingberg describes teachers' and students' roles as follows:

"In instruction teachers and learners act in a specific - pedagogically intended and didactically arranged - structure of interdependencies and conditioning factors, in a pedagogically dense constellation. The fundamental contradiction is that, on the one hand, pedagogically intended, didactically arranged (and often organized) processes influence the learner(s), in that pedagogically legitimate objectives, contents, methods, and modes of organization are intentionally directed towards their education (and consequently also aiming at change and development) so that the learners find themselves in a pedagogically and didactically intended object position - while, on the other hand, this same process can only function properly if these 'pedagogical objects' simultaneously adopt the position of a subject.

Obviously, the educational rationale consists in both the permanent synthesis of learners' synchronized, varying, overlapping subject- and object position(s) and in a linking of the teachers' subjectand object position. (...) 
Learners are neither mere subjects of pedagogically intended instructional processes nor are they objects, rather they are at the same time (direct or indirect) objects and subjects of a process which they are, on the one hand, exposed to and which, on the other hand, they co-construct." (Klingberg, 1987, pp. 8-9, own translation)

The double nature of both positions - teachers and students are at the same time subjects and objects in instructional processes - holds far-reaching consequences for lesson planning:

The first important consequence is Klingberg's conclusion that there should be taken much more note of students' didactic competence than it is the case with the established didactic models. If students are considered active 'subjects' in the instructional process, they must have didactic competence. Mr. Quandt's students' capability of profound didactic analysis, as is revealed in the group discussion, can be taken as a proof. ${ }^{9}$

A second important consequence is the refutation of the traditional assumption that the teachers are responsible for the instructional process. The teachers alone cannot steer teacher-student interaction. Our example shows that authentic student participation can only be realized under condition that the teacher accepts the subject-position of his students, as it is defined by their biographical background and their learning history.

A third important consequence is the acceptance of the fact that the students and the teacher struggle with their developmental tasks. Mr. Quandt's students cope with their insufficient foreign speaker competence, and they complain that Mr. Quandt does not accept it as starting point for his lesson planning. But he himself struggles with a similar task, self-defined and on a much higher competence level: He feels that he too should improve his English. His change of discourse from faults to mistakes, as described above, makes sense once we realize that he sees a very demanding professional developmental task in the improvement of his foreign language competence.

In order to convince my readers that the focus on 'biographical packages', on the students' didactic competence, on authentic student participation and on 'developmental tasks' et cetera is a good thing, I will identify quality criteria which should characterize didactics for learner development and educational experience. But before I will go into detail, I first want to set the frame for the overall instructional theory that I think is required.

\section{Traditional Instructional Planning and its Critique from the Perspective of Research on Learner Development and Educational Experience}

Traditional German didactics is often related to the following three classical approaches (cf. Kirsti Klette 2008, Brian Hudson 2008):

Wolfgang Klafki's Scheme for Lesson Planning ("Perspektivenschema der Unterrichtsplanung", 1991) and before that his Didactic analysis as the Core of Preparation of Instruction ("Didaktische Analyse als Kern der Unterrichtsvorbereitung", 1958/1961);

Wolfgang Schulz's Model of Lesson Planning ("Unterrichtsplanung", 1980) which highlights the notions of autonomy, participation, and competence;

and Hilbert Meyer's Action-oriented Didactics ("Handlungsorientierung"), see his guideline for lesson preparation ("Leitfaden zur Unterrichtsvorbereitung"), 1980, and Methods of Teaching ("UnterrichtsMethoden"), 1986.

Wolfgang Klafki's focus has always been on subject matter (content). He asks how teachers can help students to find something worthwhile learning, he tries to change 'subject matter' ('Bildungsinhalt') into 'educational content' ('Bildungsgehalt'). I consider this a necessary element of any didactic model (cf. Meyer \& Meyer 2007).

Wolfgang Schulz' model, in contrast, focuses on teaching and learning as a process, and on student participation. Schulz rightly criticized Klafki's approach as "metaphysical". However, Schulz himself never worked empirically, only his students did.

Hilbert Meyer brings in the students as active learners, but action orientation is not enough! Doing 
something only makes sense when it fosters learning, Dewey's learning by doing. I come back to that.

The three models conceive the instructional process from a societal point of view, as I have sketched in the scheme I started with (figure 1). They are teacher-centered and focus on subject matter, the teachers' role, and instruction, but they do not integrate the students in an adequate way. They are founded on the assumption that teaching 'produces' learning, and that the teachers are responsible for the success of the learning process of their students.

Against this traditional perspective, we argue as follows:

Students should be conceived of as persons with a biographical background and a learning history, striving to be successful concerning their developmental tasks. Following Lothar Klingberg, we construct them as 'subjects' and 'objects' of the teacher-learner interaction.

Teachers are in a developmental position similar to that of the students, since they, too, bring in their biographical background and their learning history, and strive to cope with their developmental tasks. They habitually focus on the pedagogical quality of subject matter, on the curriculum, and on the instructional process, not on the students and their developmental tasks.

From the students' point of view, subject matter is typically different from what the teachers think it to be. Students perceive the subject matter of the subjects they are taught as something that is vaguely ahead of them, a challenge, still to be dealt with, a self-chosen or - more often - an imposed task. It is not thought of as 'general education' ('Allgemeinbildung').

Let me be more explicit concerning the new perspective. I start with a quotation. Hagen Kordes comments traditional didactics very critically:

"Didactics and curricula lack what is truly important for people's genuine educational process. Teachers' intentions - finding expression in learning objectives, syllabus, teaching method and practice - take effect only on the surface and are seldom decisive factors for the students' actual learning and the real educational processes." (Kordes, 1989, p. 9; cf. Hericks/Kunze, 2005, p. 401, own translation).

Kordes' criticism may be exaggerated. Yet, it touches upon real problems:

-Though teachers know that students' learning is largely self-regulated, teachers tend to act as if they could direct educational processes in the long run, and by design.

-Busy with instruction, teachers tend to forget how students perceive the subject matter presented to them and how they deal with it.

-Curricula construct subject matter and the didactic progression concerning subject matter in such a way that they presuppose ideal students. ${ }^{10}$

I will come back to the curricular problems in the fifth section of this paper. But first, for reason of clarity, I will elaborate on the notion of learner development. We should examine to some more detail the significance of teachers' and students' being confronted with developmental tasks.

\section{Developmental Tasks}

\section{The Developmental Task Concept}

I have by now mentioned the notion of developmental tasks more than once, but I have not defined it. By developmental tasks we mean developmental objectives which learners ('subjects') construct by interpreting societal ('objective') demands. Developmental tasks are, as has been frequently emphasized by Barbara Schenk and others, the inner motor for learning (Schenk, 2001, p. 263).

School advances or prevents dealing with developmental tasks. Didactics for learner development and educational experience is therefore the theory and practice of teaching and learning, focusing on the question how students themselves design their educational career within the framework of the school system. 
The developmental task concept goes back to Robert J. Havighurst, supplemented by Uwe Hericks and Eva Spörlein (2001) and others. ${ }^{11}$ Hericks and Spörlein suggest the following developmental tasks for young adults (age group $16-20$ ):

-relation to age mates,

-gender role,

-body acceptance,

-independence from parents,

-sexual relationships,

-occupational perspectives,

-future orientation,

-system of values/ sharing responsibilities,

-self-concept.

We have portrayed, analyzed, and evaluated Havighurst's developmental task concept a number of times (cf. Trautmann, ed., 2004), so I am brief at this point. Havighurst writes:

"The developmental-task concept occupies middle ground between the two opposed theories of education: the theory of freedom - that the child will develop best if left as free as possible, and the theory of constraint - that the child must learn to become a worthy, responsible adult through restraints imposed by his society. A developmental task is midway between an individual need and a societal demand. It assumes an active learner interacting with an active social environment." (Havighurst, 1972, p. vi)

In view of the children's and juveniles' challenges it's sensible to differentiate an objective educational career with its societal demands ('objektiver Bildungsgang') from a subjective career and the student's individual needs ('subjektiver Bildungsgang'). The students' educational career gets its objective shape by the system, i.e. by institutions and organizational measures, which accompany them from first grade to graduation, and, last but not the least, through classroom instruction, so that teachers become the representatives of this objective side to them. But it is the subjects, they themselves with their self-regulatory power, who realize the societal demands in their subjective vein.

The most striking 'objective' step taken recently in Germany has been the activities of the state ministries and the Berlin Institute for Quality Development in Education ("Institut für Qualitätsentwicklung im
Bildungswesen"), its objective being to determine educational standards followed up by an exhaustive evaluation on whether or not they were met. The implementation of educational standards is a good example for developmental tasks being determined 'objectively' but 'subjectively' interpreted and dealt with. I come back to my starting quotation: Klieme et al. conceive educational standards as motor for educational school development: But we claim that this can only be a part of the 'objective' part of the students' 'subjective' educational career, and this means that half of the problem, or more, is left out in the theory building of Klieme et al. Developmental tasks are the motor of learning and education ('Bildung'). Educational standards are not enough.

\section{Developmental Tasks and General Education}

While it is traditionally the adults who explore and define for the children and juveniles the subject matter, i.e. the problems and tasks through which their education shall be advanced, we assume that within the frame of the developmental task concept, it is the students' subjective interpretation of the teachers' teaching that determines the dynamics of instructional communication and interaction and, by that, the curriculum. Therefore, I now relate the developmental tasks concept to general education ('Allgemeinbildung'), as constructed by Wolfgang Klafki in his 'critical-constructive didactics (Klafki 1985/1991; cf. Meyer and Meyer 2007).

Klafki claims that the general education program, embodied by teachers as representatives of the adult society, is obligatory and that it advances the learners' development in such a way that they can become responsible members of the adult society. Klafki more than often stresses, being very rigid here, that key problems ('Schlüsselprobleme') - world peace, ecological problems, the work load, challenges of the new information technologies, gender relations, intercultural understanding et cetera - may not be sacrificed to neither learners' nor teachers' and curriculum authors' subjectivity. The key problems curriculum allows them, as he says, to develop the faculty of self-determination, the faculty of cooperation, and the willingness to practice solidarity with those people who cannot analyse self-determination and cooperation themselves. 
If I had to put this in the words of research on learner development and educational experience, I would have to say that general education is in itself a developmental task. However, it is a nuisance that many teachers and most students of the upper secondary stage do not agree! From the elder students' point of view, general education is not a motor for learning, but rather an obstacle course to graduation. And the teachers normally forget about general education and simply take it for granted that the subject matter they teach is good for it. Let me add that the teachers presuppose that the students develop multilateral interests for all the subjects, but this is not the case, normally. Besides, they themselves restrict their interest and their competences to two or three subjects. This then means that they demand something which they themselves do not fulfill. They take it for granted that their subjects are good for general education. A sustainable theory of general education finds no place in their image of good instruction.

The traditional concept of general education becomes more complex, more demanding and more problematic in the light of the following three interrelated problems:

The first problem is that general education, being the main purpose of obligatory schooling, has to be brought in harmony with the acceptance of a plurality of world concepts, of the learners' heterogeneity, and of individualization of learning processes. To which extent do we, as representatives of the society of the grown ups, have the right to force the next generation to partake in obligatory schooling?

A second problem relates to general education's fundamental claim to globalization. What general education for globalization should look like, is, to my knowledge, not discussed in Germany, neither in empirical education research ('Bildungsforschung') nor in intercultural studies. What then would a European, or a world wide concept of general education look like?

A third problem relates to the educational standards. It should be clear by now that the implementation of educational standards - based on an implicit theory of general education - becomes a moral problem. How does the commitment to objective educational standards combine with the next generation's right to develop individuality and to acquire self-regulated "Bildung"?

I hope that my readers agree that we need more research on when and how general education and developmental tasks harmonize and when and how they produce antagonism and friction.

\section{The Instructional Framework of Didactics for Learner Development and Educational Experience}

Even though I have described many problems and only few solutions in the preceding sections, I will now develop the instructional frame of didactics and a scheme for lesson planning and teacher-student interaction.

\section{The Teacher Role}

Doing interviews with pre-service and in-service teachers (cf. Meyer/Kunze/Trautmann, 2007, Meyer 2009) reveals the great importance they attach to their own experiences from school days when they themselves were students. They repeatedly draw on those to justify their actions (cf. Neuß 2008). The number of teachers who engage in reading research literature however is small.

They usually have in mind an everyday image of good instruction and of being a good teacher which is holistic, emotionally colored, and easily retrievable, which means that it can be updated spontaneously from case to case. It is practical knowledge. It differs considerably from the knowledge disseminated in educational science and psychology. It is biased, as a rule, and it will be full of unwarranted generalizations. Educational researchers, on the other hand, focus on one or two or just a few aspects of everyday instruction, go in depth, and produce scientific 'results'. But they forget the whole of the professional demands and respective competences of the teachers.

That is why, when it comes to improving teachers' image knowledge, we have a theory-practice problem: 
The teachers' practical image knowledge has to be brought up to consciousness if it is ever to be modified. In other words: the PISA shock in itself is not enough to produce a change of teachers' thinking styles and their activity in the classrooms. That is why we hope that research on learner development and educational experience has a chance. It starts with the 'biographical package' of students and of teachers, and shows a way to the surface.

The image knowledge of teachers needs to be complemented by empirical research. However, this complementation is no simple cognitive activity. The teachers' practical everyday knowledge cannot be 'confirmed' or 'deleted' by merely contrasting it with the findings from empirical research in educational science and psychology et cetera. The reason for that is that the teachers' 'biographical package' is a cognitive and emotional filter blocking the internalization of empirical research data.
The successful confrontation of empirical instructional research with images of good instruction and good teacher performance is a very complex, difficult achievement. (cf. Meyer 2005a, 2005b). In a sense, even positive experience is negative, because the teachers cannot know whether their images are justified or not.

Our aim is, therefore, to support teacher trainees (pre-service and probationary teachers) and in-service teachers in their development as reflective practitioners, shifting from 'negative' school-time subjectivity to 'positive', present day reflective subjectivity. In other words: We believe that there is a way to sustainable individual didactics and to reflective practice, if the teachers get a chance to make their own professional developmental tasks explicit. In a sense, even positive experience is negative, because the teachers cannot know whether their images are justified or not.

The following diagram is meant to describe my position in short:

\section{The Teacher's $\mathrm{Own}$}

Ex perience

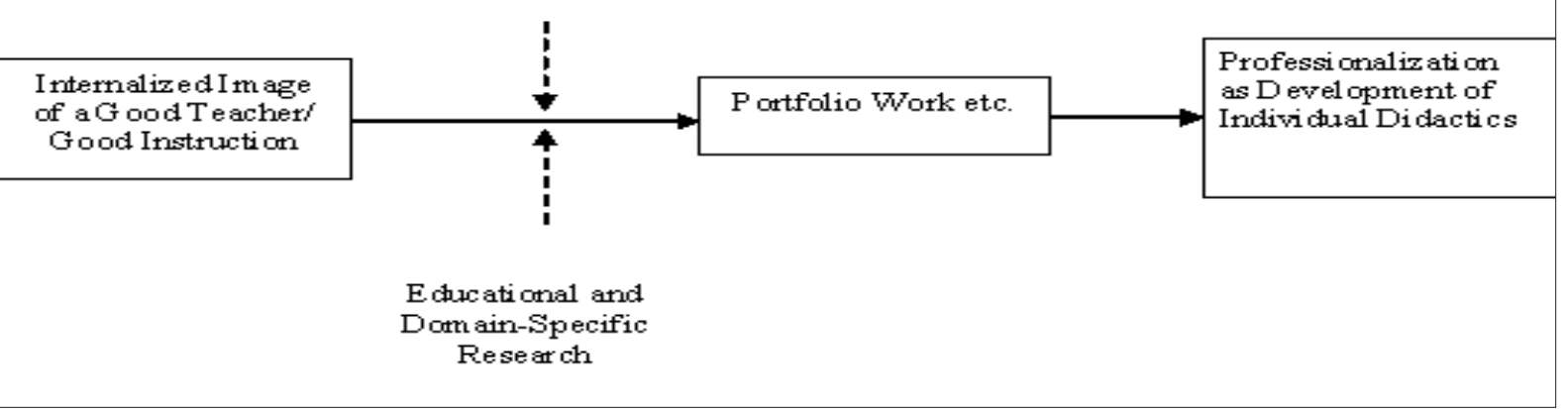

Fig. 3: The teacher role from the perspective of research on learner development and educational experience

In the following paragraphs I will further elucidate the concept and illustrate how research on learner development and educational experience can shed light on students' and teachers' perspectives, on lesson-planning and on teacher-student interaction in innovative ways.

\section{Twelve Quality Criteria for Instruction based on Research on Learner Development and Educational Experience}

Traditional advice for instructional planning - I have referred to Wolfgang Klafki, Wolfgang Schulz, 
and Hilbert Meyer above - has been rightly criticized by exponents of empirical education research such as Jürgen Baumert, Eckhard Klieme, Manfred Prenzel, Heinz Mandl, Andreas Krapp, and others for their slim or totally missing empirical grounding.

We can take, once more, Wolfgang Klafki's didactics, as an example for that. The question of how to verify whether - in a given classroom situation - educational subject matter ('Bildungsinhalt') has actually been transformed into educational content ('Bildungsgehalt') was and is even today fairly unsettled, despite today's methodological instruments that were not available when Klafki devised his theory in the 1950's.

The problem with Hilbert Meyer's action-oriented didactics is comparable. How should one devise an empirical research program that gives backing for the positive effect of action oriented instruction on the students' learning?

This means that the issues didacticians traditionally cope with are more complex than the issues empirical education research can deal with, and that is why the quality criteria set out in the following result from an interplay for which I have compared the state of research on instructional planning and teacher-student interaction with what has been empirically gathered in a Hamburg University $\mathrm{PhD}$ Graduate School and around it:

(1) We should deal with both teachers' and students' developmental tasks. I wrote about that above, and I will come back to it in the next section.

(2) Students and teachers are mutually required to balance out their commitment to developmental tasks and their commitment to general education ('Allgemeinbildung'). ${ }^{12}$ I have elaborated this difficult problem above as well.

(3) Teachers should accept that the future is uncertain and draw their conclusion from this (cf. Meyer, 2003). They have to teach as if they knew what the students need for life; but they can only hope that the teaching aims are acceptable, that the contents they teach is actually meaningful, understandable and acceptable for students, and that their methodology is a help for learning. ${ }^{13}$
(4) We have to accept that, in a way, teachers can only demonstrate what is to be learned while learners' progress comes self-directed. This approach results in an as-if-didactics. We have to teach as if there was a stable bridge from teaching to learning. That is why teachers should accept the necessity of practicing open planning, which would allow students to cooperate with them, as stated by Klingberg (1987).

(5) This, in turn, justifies a view on didactics as the art of teaching ('Lehrkunstdidaktik') (cf. Berg/ Schulze, 1998; Berg/Klafki, 2001). In political instruction, Andreas Petrik, Stefan Hahn et al. (2007) have shown, in their project on a 'village foundation', that the 'objective' curricular demands and students' 'subjective' experience can be harmonized to some extent, against Hagen Kordes' view cited above, in open curricular settings.

(6) We have to accept competence orientation: Introducing competence-oriented instruction and exploring competence levels is a must, as far as I am concerned. The reform has to be domainspecific: Interlanguages, learner literature, learner mathematics, learner physics, levels of historical consciousness, levels of intercultural competence etc. should be the starting point for instructional planning (cf. Meyer-Hamme, 2009; Klieme et al., 2003; Prenzel/Gogolin/Krüger, 2007).

(7) Focusing on the zones of proximal development is a promising approach for lesson planning (Wigotski [= Vygotskij], 1934/2003, pp. 298 ff.; cf. Gedaschko, forthcoming) because, as stated above, students usually possess considerable didactic competence. Making use of this resource is a very important element of our didactics of learner development and educational experience. Students' participation in instructional settings is based on their current didactic competence and its development; it is not restricted to their current and developing subject matter competence.

(8) The way students are able to contribute to instruction and teachers are able to include them is directly related to the objective of self-regulated learning (cf. Boekaerts et al., 2000; Merziger, 2006) and to self-determination in learning processes (cf. Klafki 1985/1991; Deci and Ryan, 2002; Lechte, 2008). The tense relationship of teacher guidance 
within the developmental zones on the one hand, and self-regulation/ self-determination on the other hand, makes student participation a central task in the development of teaching methods.

(9) Instruction has to enable students to experience authenticity (Hericks, 1998; Meyer/Kunze/ Trautmann, 2007), for which I have given my example in the third section ${ }^{13}$. Mr. Quandt's students construct their own instructional theme against the teacher's original intention. This means it is desirable for teachers to be receptive to instances of authenticity in the classroom. But they should know that authentic learning occurs, it cannot be planned by the teacher.

(10) The interest in authenticity is linked to the necessity to take students' everyday fantasies, which they contribute to the instructional process, into consideration. There is evidence of the fantasies' positive effect on biology instruction (Gebauer/ Gebhard, 2005; Born, 2006; Monetha, 2008). There is no reason to assume that this should be any different in other domains and other subjects of study.

(11) It should be obvious that great importance is attached to consulting students and to students' feedback to teachers in didactics for learner development and educational experience (cf. Bastian/Combe/ Langer, 2003; Flutter and Rudduck, 2004; Thomson and Gunter, 2006; Rudduck and McIntyre, 2007). Consulting pupils needs to become a matter of course whenever we deal with instructional planning.

(12) The last and most important quality criterion for classroom interaction focuses on the importance of sense-making ('Sinnkonstruktion') for instructional planning and teacher-student interaction. From the perspective of research on learner development and educational experience, organizing the teacher-student interaction according to teaching aims is not enough. Instruction has to be linked to the students' sense making, because it supersedes the teachers' intentions. ${ }^{15}$

Let me be more explicit concerning the central concept of sense-making: Teaching intends learning. okay. But students will start their learning only when the teachers' teaching makes sense for them. Successful sense-making is like a filter with respect to the interaction of teachers and learners. In John Dewey's terms, sense-making is a basic requirement for negotiation of meaning. Consequently, sensemaking, experience, and developmental tasks turn into key concepts for lesson planning and for didactics from the point of view of learner development and educational experience.

The following diagram should now be 'readable':

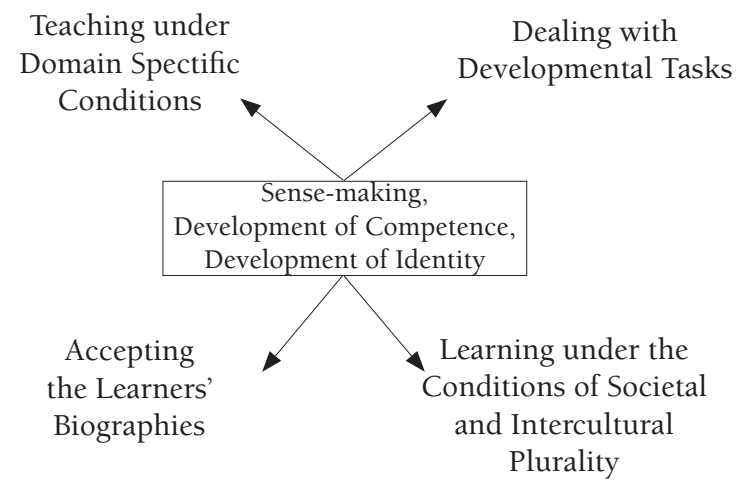

Fig. 4: Sense-making within the instructional process

It has to be accepted that teachers' and students' sense-making is dependant on their social and cultural background. Therefore, teachers' and students' 'biographical package', their heterogeneity and, by that, a plurality of world views and self-concepts have to be accepted for the instructional process. Students will always argue from their own biographical background, which is directly connected to the anticipation and construction of their personal future. Learners are not empty bowls to be filled with subject matter. ${ }^{16}$

Let me reaffirm the message set forth in the diagram: Teaching and learning only define one axis of the instructional diagram. Naturally, they have to be considered by teachers and students in lesson planning and classroom performance. Learner biographies, learner development, educational experience, and developmental tasks, however, constitute the other axis. Sense-making is like a filter. Sense-making that advances learning in school becomes possible when the four elements, teaching and learning, and biographical background and developmental tasks, are in harmony. 'Harmony', however, is bound by the dialectical relationship of teacher-learner interaction and the past and future direction of learners' biographies and developmental perspectives. 


\section{Learners' and Teachers' Developmental Tasks}

The kind of developmental tasks juveniles are confronted with have been frequently described in the context of our graduate school (cf. Hericks/ Spörlein, 2001, and Trautmann, 2004) and by other scholars. However, with respect to the interplay of teachers' and students' developmental tasks, we do not yet have many empirical data, even though it is obvious that the teachers' former student biography is important, as exemplified in the second section. Studying the interplay will considerably improve the understanding of teacher-student interaction.

Some children already know in elementary school that they want to become a teacher. Others know for certain, in senior high school (upper secondary stage), that they do not want to become a teacher. However, all of them develop, consciously or unconsciously, didactic competences, and some of them will build up explicit and reflected professional knowledge and skills while being in teacher training. So, if we imply that there is such a thing as professional developmental tasks, we have also to accept that there are developmental stages, leading from infant life and school to the teaching profession (cf. Meyer, 2005b, p. 32).

Uwe Hericks deals wit a part of this development. He applies Havighurst's concept of developmental tasks (1948/1972) to teacher training. He identifies four developmental tasks, pre-service and young in-service teachers are confronted with:

-The development of competence and a controlled, effective dealing with own skills, including dealing with the deficits, which any competence profile naturally involves,

-the development of the ability to mediate (transfer) acquired knowledge and competence, to impart it to others, ${ }^{17}$

-the development of the ability to acknowledge the students' otherness instead of constructing a nonreflected image of the good student in analogy to the own image of a good teacher, and -the development of the ability to interact within the school system - not only with the heads of training, mentors, and principals but, in particular, with one's own colleagues within a community of practice (Hericks/Kunze, 2005; Hericks, 2006, pp. 92 - 138).

In order to facilitate my argument that students and teachers both cope with their developmental tasks and that accepting this is a condition for successful classroom instruction, I group the adolescents' developmental tasks, as identified by Uwe Hericks and Eva Spörlein (Hericks/Spörlein, 2001, p. 36), and the developmental tasks of pre- and in-service teachers (Hericks 2006) to four developmental clusters.

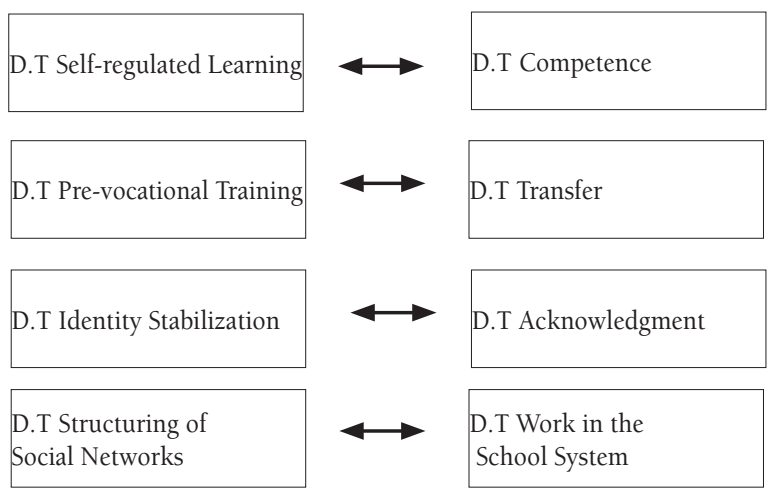

Fig. 5: Students' and teachers' developmental tasks

The juxtaposition of students' and teachers' developmental tasks appears sensible to me, because teachers' developmental tasks can well be interpreted as job-related variations of juveniles' developmental tasks:

-Students are learners, teachers are learners, as I have demonstrated above. As far as the structuring of their expertise is concerned, teachers are, at least from the adolescents' point of view, at a very advanced state, even though in Hamburg, for example, the majority of probationary teachers ('Referendare') over the last years expressed that they felt insufficiently prepared for their future job. Making explicit that both sides are learners will be helpful for classroom management and effective instructional cooperation. 
specification of the theme

with regard to domain specific conditions, science, and educational
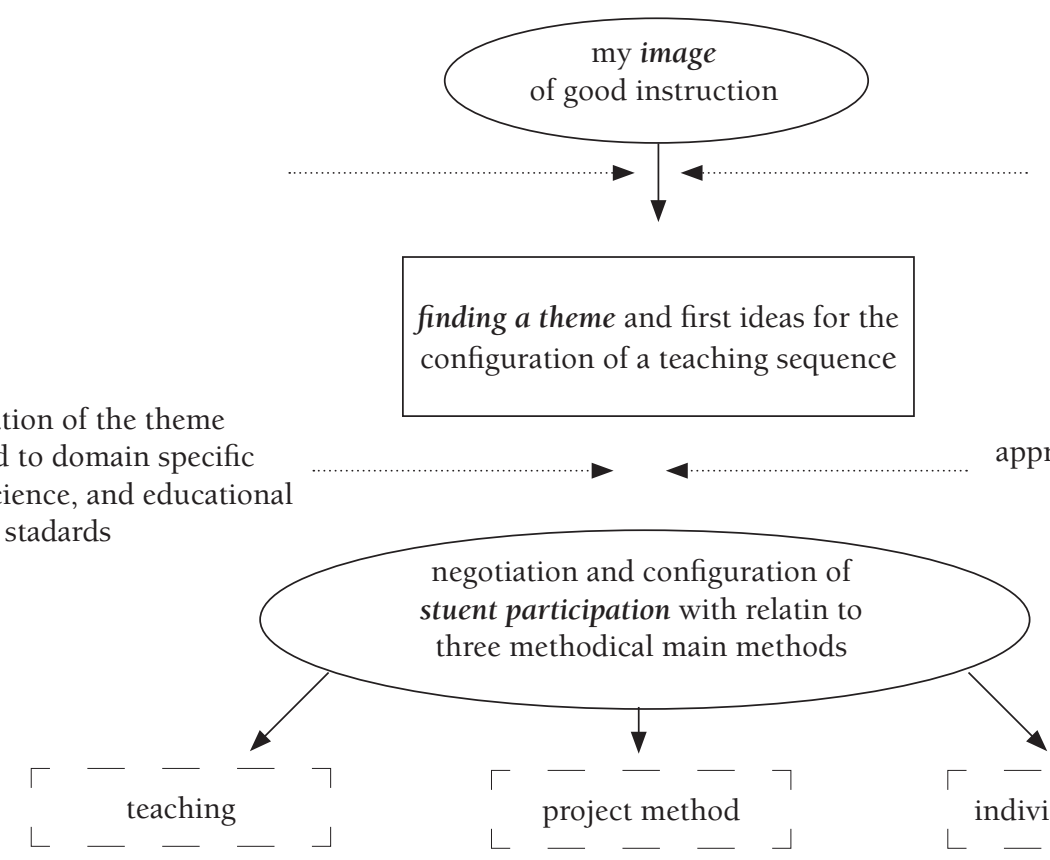

finding a theme and first ideas for the
configuration of a teaching sequence

finding a theme and first ideas for the
configuration of a teaching sequence

stadards

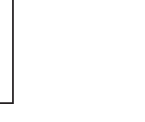

approaching theme from the angle of its sense (Sinnhaftigkeit)

negotiation and configuration of stuent participation with relatin to three methodical main methods

Quality criteria: (1) Linking of teachers' and students' developmental tasks, (2) Balancing out the fulfillment of developmental tasks with the commitment to general education, (3) Uncertainty and (4) as-if-didactics, (5) Art of teaching (Lehrkunststücke), (6) Competence orientation (learner language, learner mathematics, historical consciousness, ect), (7) Students' didactic competence and students' participation, (8) Se»lf-regulation / Self-determination, (9) Promoting authentic learning situations, and (10) alowing for everyday fantaisies, (11) Feedback and consulting, (12) Sense-making as a basis for competence and identity development
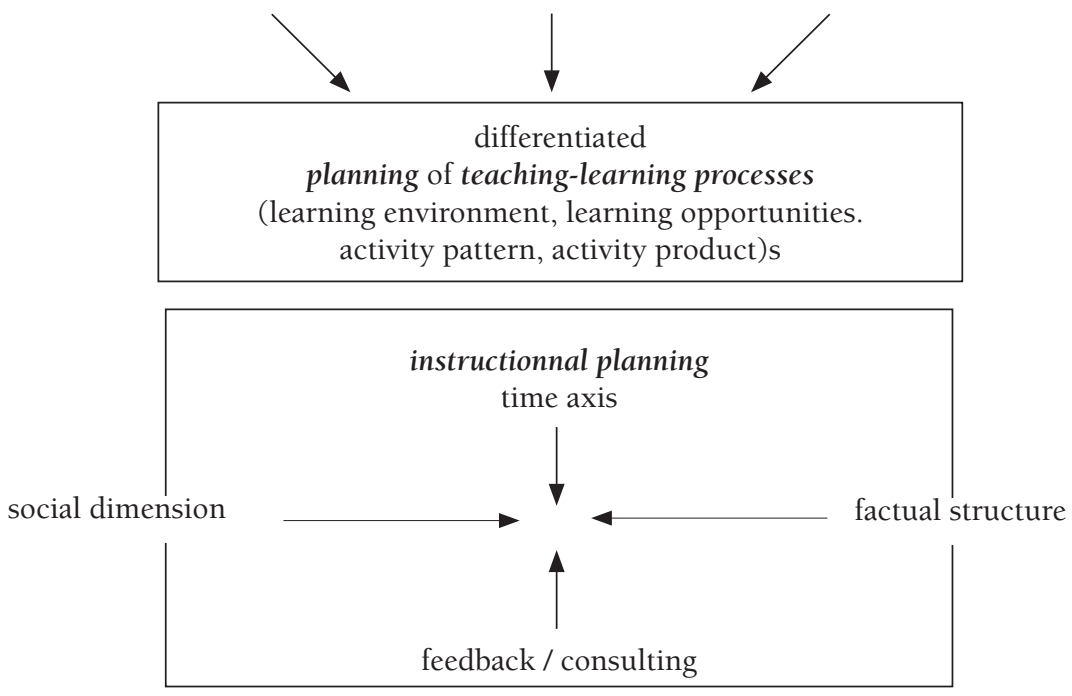

Fig. 6: Instructional planning from the perspective of research on learner development and educational experience 
-While teachers and pre-service (probationary) teachers are already working professionally, the task of qualifying for a job is still ahead of juveniles and young adults. Realizing common ground in this respect should be a bridge for cooperation.

-We know that a good classroom climate is an important factor for successful classroom interaction. And this, in turn, depends on mutual acknowledgement of students as novices and teachers as expert learners. It is first the willingness but then, of course, also the ability to acknowledge students' 'otherness" that allows teachers to assist students in finding and stabilizing their identity.

-As documented by Hericks (2006), structuring a social network of, for example, supportive elder colleagues or co-probationary teachers is of great importance to survival within the school system. Similarly, structuring a social network is a developmental necessity for juveniles when it comes to 'cutting the cord' from home.

\section{An Instructional Planning Scheme}

Although didactics for learner development and educational experience allows for empirical findings, it still maintains its status as an action-oriented discipline with normative implications. You find a scheme for instructional planning from the perspective of learner development and educational experience on the preceding page.

\section{Didactic Reflections concerning levels of teacher-student interaction}

What changes and what remains the same if one sets out anew to examine the realm of didactics from the perspective of research on learner development and educational experience? On a superficial level, the first part of the question is easily answered: After TIMSS and PISA, we should think competence-oriented, and seek competence levels for student assessment. The second part is more difficult: The levels of student competence have to be related to instructional interaction, to transfer, and, from a methodological point of view, to a concept of student participation. What we need then is levels of instructional planning and teacherstudent interaction. Identifying levels of teachers' teaching competence and students' subject matter competence is not enough.

To my opinion, there are three levels of interaction and cooperation in the instructional process. (I leave open a zero level at which learning does not take place.) The following scheme is meant to describe the qualitative difference of the three constructions of teacher-student interaction as I see it. What connects the three levels is the notion of mediation or transfer ('Vermittlung') as a central didactic category. Teacherstudent interaction is meant to produce transfer of knowledge, of competence, of skills, of behavior and attitudes. However, the meaning of transfer changes on the different levels.

Intergenerational communication regarding stabilization or transfor-mation of next generation's world- and self-concept on the basis of transfer of knowledge, skills and attitudes.

Transfer of knowledge, skills and attitudes as a product of negotia-tion in a community of practice of learners and teachers, gaining advantage from learners' didactic competence.

Third level

Transfer of knowledge, skills and attitudes as the task to instruct students and on the other side students' adaptation to teachers' demands.

Fig. 7: Levels of didactic interaction and cooperation 
The first level deals with describing the surface state in which teacher and learners are. The teacher leads the class, and the students do what he wants them to do. It is the phenomenological (or: ethnographical) level and does not need specific educational knowledge for its description.

However, educationally experienced observers will see that it has to be possible for teachers and students to invest their didactic competence into lesson planning and teacher-student interaction. Therefore, the focus of a second level is the description of the communicative structure of teacherstudent interaction as it can be realized in a community of practice (cf. Meyer 2005a).

The third level then is intergenerational communication and negotiation as a condition for 'Bildung', and the respect teachers show towards their students and vice versa.

Let me relate my further explanation of the scheme to my experience as a university teacher. If beginning university students who want to become teachers do their internship and write a report on that, I very often read that the teacher they watched had a good mastery of the class, a good grip on them. And they mean by that that the pupils do what the teachers want them to do. Within Lothar Klingberg's didactical theory, we can say that beginning pre-service teachers mostly see their students as objects, not as subjects of the instructional process. They construct the teacher as the one who does it. They conceive learning as caused by teaching.

I accept that this is what my students 'have seen', but it is certainly not what the teachers themselves would tell me. They normally see problems, they do not have the feeling of being in control of the class, they identify communicational problems, they report on students' family problems, on difficulties with subject matter material, et cetera. This means that the phenomenological description of classroom instruction, as presented by the teacher students, is not simply erroneous, but that it is rather unsettled, it is only a necessary first reflective step. At this first level, the inexperienced pre-service teachers observe the students' adaptation to the teacher's demands. We are forced to acknowledge that that is not enough. ${ }^{18}$

The first level then has to be transformed into a level at which communication, sense-making and negotiation of meaning can be seen. Otherwise, the teacher and the students would remain in their 'object' position of the first level. In other words: if we assume for teachers and learners an equal, simultaneous subject- and object-position, we inevitably reach a higher construction level, a communicative level, at which instruction implies production and hence negotiation of meaning and sense production. We are able to see sense-making as the 'filter' I talked about above.

It is important for me that the description of teacher-learner interaction at this second level is once more unstable. The sense-making and the meaning that teachers and students can attach to classroom activities, can be identified, but it still does not come into focus adequately. Educational sense-making is more than and different from what any linguistic description of classroom interaction or any sociologically founded discourse analysis can yield. Educational sense-making indicates a third level, a level of teachers' and students' mutual acknowledgment of a common educational task in spite of differences. After the phenomenological and the communicative turn, we have, as I see it, to construct a genuinely pedagogical educational framework for the description of teacher-student interaction and cooperation. The key concepts for the description of teacher-learner interaction at this level are intergenerational exchange and acknowledgement. They allow negotiation of teaching and learning aims, they allow acceptance of otherness, and by that they relate to Uwe Hericks' third professional developmental task, acknowledgement. It's only now, after phenomenology and communication theory, that 'Bildung' has a stake in this theory. The twelve quality criteria i described above mostly refer to this level.

As for this, I refer to Helmut Peukert's educational theory. He writes:

"Especially where adults act as representatives of a historically developed language and culture, they 
have to assume a subjective potential of the capacity to act, the faculty of creative reconstruction and new construction - all of which cannot be eliminated towards the child. A transcendental analysis of the assumed liberty potential becomes meaningful: making use of children's and juveniles' educational potential does not imply that they are clay in the educator's hand, but describes a potential liberty structure of the children (...). Especially under the conditions of asymmetry, the educator's pedagogical activity has first of all to assume a liberal mutuality that does not refrain from, but rather commits itself to make areas of potentiality for the construction of an own world and an own self innovatively accessible to children and juveniles." (Peukert, 2000, p. 520, own translation)

Peukert, in his outstanding paper, answers the question how education ('Bildung') can be thought today. However, he does not give an answer to the question what a didactics of transformation should be like. I assume that our didactics for learner development and educational experience, as I have described it above, can be of help in this difficult situation. The key concepts for such a truly didactic educational theory are the transformation of worldview and self relationship.

I hope that the three levels of didactic interaction and cooperation described now can be operationalized, with the help of experienced teachers and didacticians in future research projects (cf. Meyer 2005a, 2009).

\section{Final Comment}

Looking back at the preceding seven sections of this paper, it should by now be clear that the dialectical relation of self-determination and societal demands was the frame for my argumentation. I started with the present-day situation in didactics and the focus on learner development and educational experience ('Bildungsgangforschung') in our Hamburg University PhD Graduate School. I then developed the idea of authenticity in student participation in the classroom with the help of a short example. I outlined the developmental task concept, and described the problematic status of this concept with regard to general education. This made it possible to sketch a new teacher role within our framework and to define quality criteria for instructional planning which allow teachers to develop their individual didactics. I stated that teacherstudent interaction, to a considerable extent, depends on the 'biographical package' and the developmental tasks of students and teachers, and this means that we need a new scheme for instructional planning and teacher-student interaction. This scheme has to include levels of competence which increase the realization of cooperation and individual freedom of teachers and students. I hope to have sketched a vision of 'Bildung', a concept for domain-specific education, and a strategy for learner development that can serve as motor for the improvement of our schools. 


\section{NOTES}

1. It is difficult to translate the notion of 'Bildungsgang' into English, because there are two fundamental meanings to it, learner development on the one hand, and the educational experience the learner has in and out of school, on the other hand.

2. Our program for the Hamburg University PhD Graduate School on Learner Development and Educational Experience, which was funded by the German Research Association, may be of some help for a first understanding of our concept: "Research on learner development and educational experience ('Bildungsgangforschung') is first of all teaching-learning research. It lays emphasis on the learners' perspective by focusing on the educational course and the school curriculum. Education is a process of socialization during which the self develops, with crises, regressions, ruptures, developmental leaps, and interruptions. Therefore, the advancement of education requires conditions that secure society's reproduction, but at the same time allow for societal transformation. Our studies are concerned with juveniles' and young adults' behavior in teaching-learning situations, how they interpret their learning tasks, and what can be done in order to advance their educational processes. We are interested in how juveniles and young adults, acting in a world becoming increasingly complex and difficult, develop not only knowledge and skills, but also simultaneously the faculty of self-determination and responsibility." (Text of application, Bastian et al., 2001, p. 3, ref. Homepage of the Faculty of Educational Science, University of Hamburg)

3. This paper is an enlarged and substantially corrected version of a German paper: "Unterrichtsplanung aus der Perspektive der Bildungsgangforschung", published in: Meinert A. Meyer, Manfred Prenzel, and Stephanie Hellekamps, Eds. (2008). Perspektiven der Didaktik, Sonderheft 9, Zeitschrift für Erziehungswissenschaft, p. 117 - 137. I thank Angela Sander-Nöthel and Margarita Giannoutsou, Hamburg, for a translation of the text which served as the basis for this English paper.

4. The book on student participation in English instruction published by Meinert A. Meyer, Ingrid Kunze and Matthias Trautmann (2007) contains far more in-depth expositions on this subject. I also want to refer to Christine Ziegler's parallel study on student participation in science instruction (2008) and to Ralf Schmidt's study on history instruction (2004).

5. For special reference - here and below - cf. Meinert A. Meyer, Ingrid Kunze and Matthias Trautmann (2007).

6. I'd like to point out that during our research we frequently met with this clichéd view both among teachers and learners - the teacher does the instruction.

7. Age group 12 to 13, equivalent to sixth grade high school.

8. Lothar Klingberg was the leading didactician of the German Democratic Republic, and the only one who was read and accepted in both parts of Germany.

9. An evaluation of all student interviews showed that they argue on a high level of didactic competence which at times exceeds the teachers' competence (cp. Meyer, Kunze, Trautmann 2006).

10. In Mr. Quandt's class, the students complain that he wants them to know the vocabulary they had learned 6 years before. One may take this complaint as a simple example for the dilemmata of didactic progression. As I see it, bearing in mind Dewey can be helpful in order to develop a dialectical view on learners' relationship to subject matter (cf. "The Child and the Curriculum", 1902/1976, p. 278). 
11. Though holding it in high esteem, we have criticized Havighurst's model, because it is too dogmatic in some respects. With comparatively little reflection it sets up the white American middleclass as a frame for argumentation.

12. The definition and verification of compliance with educational standards is the current operationalization of linking developmental tasks and general education. As I have explained above, establishing educational standards requires an alignment of educational contents and methods, because objectives, contents, and methods are interdependent.

13. I can put this into the language of Richard Rorty's neo-pragmatism: What we need in didactics is a theory of hope, not of truth (cf. Rorty 1989, and Meinert Meyer and Hilbert Meyer 2007).

14. I would like to point out that in this context the meaning of didactic authenticity is different from what is understood elsewhere by 'authentic teaching situations' or 'authentic texts' (i.e. texts which have not been edited didactically).

15. I would like to point to the extensive literature from philosophical hermeneutics (Heidegger, Gadamer), phenomenology (Husserl, Waldenfels, Meyer-Drawe), sociology (Schütz, Berger/Luckmann) etc. on sense, sense-making, sense-finding (Sinnfindung), interpretation etc. It is astonishing that so far the concept has only been dealt with as a side issue within the field of instructional planning (cf. Combe/Gebhard, 2007). This calls for an application to and translation into concrete didactical categories, which is currently pursued at our $\mathrm{PhD}$ Graduate School (cf. Koller, ed. 2008).

16. Straub (1999) points out that identity and understanding are linked and that there are complex identity attributes, depending on the respective circumstances. The Turkish girl's identity at home is different from what it is in her German classroom.

17. I should point to the fact, that the German equivalent of 'transfer', 'Vermittlung', is not a uni-directional concept. Teachers and students produce transfer.

18. I refer to Dewey at this point. In Experience and Education (1936/1991) he states that experienceoriented instruction has to be designed in such a way, that learners reach higher levels of experience via self-directed learning. What Dewey has established as the good teachers' task, is good for the construction of a model of levels of teacher-student interaction and cooperation. We have to find a methodology which leads to more complex and, hence, more adequate levels of perception. 


\section{REFERENCES}

Bastian, Johannes, Combe, Arno and Langer, Roman (2003). Feedback. Weinheim and Basel : Beltz Verlag.

Bastian, Johannes, Meyer, Meinert A. et al. (2001). Appliance for a PhD Graduate School on 'Learner Development and Educational Experience' and its advancement. (Manuscript) Hamburg: Homepage of the Faculty of Educational Science, University of Hamburg.

Berg, Hans-Christoph and Schulze, Theodor (Eds.) (1998). Lehrkunstwerkstatt II. Berner Lehrstücke im Didaktikdiskurs. Neuwied, Kriftel : Luchterhand Verlag.

Berg, Hans-Christoph, Klafki, Wolfgang and Schulze, Theodor (Eds.) (2001). Lehrkunstwerkstatt IV. Unterrichtsvariationen. Menschenhaus - Gotteshaus. Neuwied, Kriftel : Luchterhand Verlag.

Boekaerts, Monique, Pintrich, Paul R. and Zeidner, Moshe (Eds.) (2000). Handbook of Self-Regulation. San Diego, California: Academic Press.

Born, Barbara (2006). Lernen mit Alltagsphantasien. Zur expliziten Reflexion impliziter Vorstellungen im Biologieunterricht. VS Verlag für Sozialwissenschaften, Wiesbaden

Combe, Arno, and Gebhard, Ulrich (2007). Sinn und Erfahrung. Zum Verständnis fachlicher Lernprozesse in der Schule. Opladen and Farmington Hills: Verlag Barbara Budrich.

Dewey, John (1916/1966) "Democracy and Education.” The Free Press/Macmillan Publishing Co., New York, and Collier Macmillan Publishers, London

Dewey, John (1938). "Experience and Education." New York, The Macmillan Company

Flutter, Julia, and Rudduck, Jean (2004). Consulting Pupils. What's in it for schools? London and New York: Routledge.

Gebauer, Michael, and Gebhard, Ulrich (Eds.) (2005). "Naturerfahrung. Wege zu einer Hermeneutik der Natur," in : Die Graue Edition. Zug/Switzerland : Prof. Dr. Alfred Schmid-Stiftung.

Gedaschko, Andreas (forthcoming). Sinnkonstruktionen beim selbständigen Experimentieren im Physikunterricht. (Doctoral thesis) Hamburg.

Hahn, Stefan (2007). Identitätsdiskurse und Demokratie - Lernen im Unterricht. Opladen and Farmington Hills: Verlag Barbara Budrich.

Havighurst, Robert J. (1948/1972). Developmental Tasks and Education. 3d edition 1972. New York : Longman Inc..

Hericks, Uwe (1998). "Schule verändern, ohne revolutionär zu sein ? Bildungsgangforschung zwischen didaktischer Wissenschaft und Schulpraxis," in : Meyer, Meinert A. und Reinartz, Andrea (Eds.). Bildungsgangdidaktik. Opladen : Leske + Budrich, pp. 290-302.

Hericks, Uwe (2006). Professionalisierung als Entwicklungsaufgabe. Rekonstruktionen zur Berufseingangsphase von Lehrerinnen und Lehrern. Wiesbaden : VS Verlag für Sozialwissenschaften.

Hericks, Uwe (2008) : Bildungsgangforschung und die Professionalisierung des Lehrerberufs - Perspektiven für die Allgemeine Didaktik. In : Meinert A. Meyer, Manfred Prenzel, and Stephanie Hellekamps (Eds.) : Perspektiven der Didaktik, Special edition 9, Zeitschrift für Erziehungswissenschaft, p. 61-75.

Hericks, Uwe, and Spörlein, Eva (2001). "Entwicklungsaufgaben in Fachunterricht und Lehrerbildung. Eine Auseinandersetzung mit einem Zentralbegriff der Lehrerbildung," in : Hericks, Uwe et al. (Eds.) Bildungsgangdidaktik. Perspektiven für Fachunterricht und Lehrerbildung. Opladen : Leske + Budrich, pp. 33-50.

Hudson, Brian (2008): Didaktik Design for Technology Supported Learning. In : Meinert A. Meyer, Manfred Prenzel, and Stephanie Hellekamps, (Eds.). Perspektiven der Didaktik, Special edition 9, Zeitschrift für Erziehungswissenschaft, p. 139-157.

Klafki, Wolfgang (1959). Das pädagogische Problem des Elementaren und die Theorie der kategorialen Bildung. 3d/4th edition 1964. Weinheim/Bergstr. : Verlag Julius Beltz. 
Klafki, Wolfgang (1958/1963). „Didaktische Analyse als Kern der Unterrichtsvorbereitung“. First publication in : Die deutsche Schule", Heft 10/1958. Reprinted in : Studien zur Bildungstheorie und Didaktik. Verlag Julius Beltz, Weinheim etc. 1963, S. 126-153. English translation: „Didactic analysis as the Core of Preparation of Instruction." In: Ian Westbury et al. (Eds.): Teaching as a Reflective Practice. The German Didaktik Tradition. Lawrence Earlbaum Associates, Publishers, Mahwah, Newy Jersey, and London (2000), pp. 139-160

Klafki, Wolfgang (1985). "Konturen eines neuen Allgemeinbildungskonzepts," in : Neue Studien zur Bildungstheorie und Didaktik. Zeitgemäße Allgemeinbildung und kritisch-konstruktive Didaktik. Weinheim and Basel : Beltz-Verlag (2nd revised edition 1991 : Grundzüge eines neuen Allgemeinbildungskonzepts. Im Zentrum : epochaltypische Schlüsselprobleme. pp. 43-81).

Klafki, Wolfgang (1985/1991). "Grundzüge eines neuen Allgemeinbildungskonzepts. Im Zentrum : epochaltypische Schlüsselprobleme." In : Neue Studien zur Bildungstheorie und Didaktik. Zeitgemäße Allgemeinbildung und kritisch-konstruktive Didaktik. Weinheim and Basel : Beltz-Verlag 1991, pp. 250-284 (Revised version of „Konturen eines neuen Allgemeinbildungskonzepts“, 1985)

Klette, Kirsti 82008) : Didactics meet Classroom Studies. In : Meinert A. Meyer, Manfred Prenzel, and Stephanie Hellekamps, Eds. (2008). Perspektiven der Didaktik, Special edition 9, Zeitschrift für Erziehungswissenschaft, pp. 101-114.

Klieme, Eckhard et al. (2003). Expertise: Zur Entwicklung nationaler Bildungsstandards. Bonn : Bundesministerium für Bildung und Forschung (Ed.).

Klingberg, Lothar (1987). "Überlegungen zur Dialektik von Lehrer- und Schülertätigkeit im Unterricht der sozialistischen Schule," Potsdamer Forschungen C. 74. Potsdam : Pädagogische Hochschule 'Karl Liebknecht'.

Koller, Hans-Christoph (Ed.) (2008). Sinnkonstruktion und Bildungsgang. Zur Bedeutung individueller Sinnzuschreibungen im Kontext schulischer Lehr-Lern-Prozesse. Opladen and Farmington Hills : Verlag Barbara Budrich.

Kordes, Hagen (1989). Didaktik und Bildungsgang. Münster : Lit Verlag.

Olaf Köller (2008) : Bildungsstandards in Deutschland : Implikationen für die Qualitätssicherung und Unterrichtsqualität. In : Meinert A. Meyer, Manfred Prenzel, and Stephanie Hellekamps, Eds. : Perspektiven der Didaktik, spezial edition 9, Zeitschrift für Erziehungswissenschaft, pp. 47-60.

Lüders, Jenny (2007). Fachkulturforschung in der Schule. Opladen and Farmington Hills : Verlag Barbara Budrich.

Merziger, Petra (2007). Entwicklung selbstregulierten Lernens im Fachunterricht. Opladen und Farmington Hills : Verlag Barbara Budrich.

Meyer, Hilbert (1980). Leitfaden zur Unterrichtsvorbereitung. Königstein/Ts. : Scriptor Ratgeber Schule, p. 229 (and later editions).

Meyer, Hilbert (1987). UnterrichtsMethoden. Theorieband. vol. 1 and Praxisband. vol. 2. Frankfurt am Main: Cornelsen Scriptor (and later editions).

Meyer, Meinert A. (2003). "Zeigen und Lernen - Didaktische Reflexionen im Anschluss an Ludwig Wittgenstein," in : Helsper, Werner, Hörster, Reinhard und Kade, Jochen (Eds.) Ungewissheit. Pädagogische Felder im Modernisierungsprozess. Weilerswist : Velbrück Wissenschaft, pp. 119-141.

Meyer, Meinert A. [2005 ( = 2005a)]. "Stichwort: Alte oder neue Lernkultur," Zeitschrift für Erziehungswissenschaft 1, pp. 5-27.

Meyer, Meinert A. [2005 ( = 2005b)]. "Die Bildungsgangforschung als Rahmen für die Weiterentwicklung der Allgemeinen Didaktik," in : Schenk, Barbara (Ed.) Bausteine einer Bildungsgangtheorie. Wiesbaden : VS Verlag für Sozialwissenschaften, pp. 17-46.

Meyer, Meinert A.(2007). "Entwicklung als Aufgabe. Zum Fremdsprachenlernen aus der Perspektive der Bildungsgangforschung," in : Decke-Cornill, Helene, Hu, Adelheid and Meyer, Meinert A. (Eds.) Sprachen lernen und lehren. Die Perspektive der Bildungsgangforschung. Opladen: Verlag Barbara Budrich, pp. 19-42. 
Meyer, Meinert A. (2008). „Unterrichtsplanung aus der Perspektive der Bildungsgangforschung.“ In : Meyer, Meinert A., Prenzel, Manfred, and Hellekamps, Stephanie (Eds.) : Perspektiven der Didaktik, Sonderheft 9, Zeitschrift für Erziehungswissenschaft, pp. 117-138.

Meyer, Meinert A. (2009). „Bildungsgangdidaktik aus historischer und empirischer Perspektive.“ In : Görlich, Christopher D. V. (Hrsg.) : Das lernende Subjekt. Aufsätze, Books on Demand GmbH, Norderstedt, pp. 83-150.

Meyer, Meinert A., and Meyer, Hilbert (2007). Wolfgang Klafki. Eine Didaktik für das 21. Jahrhundert? Weinheim and Basel : Beltz Verlag.

Meyer, Meinert A., Kunze, Ingrid, and Trautmann, Matthias (Eds.) (2007). Schülerpartizipation im Englischunterricht. Eine empirische Untersuchung in der gymnasialen Oberstufe. Opladen : Verlag Barbara Budrich.

Meyer-Hamme, Johannes (2009). Historische Identitäten und Geschichtsunterricht. Fallstudien zum Verhältnis von kultureller Zugehörigkeit, schulischen Anforderungen und individueller Verarbeitung. Schriften zur Geschichtsdidaktik. Bd. 26, Idstein

Monetha, Sabrina (2008). Zum Einfluss von Alltagsphantasien auf Lernmotivation und Lernleistung. Verlag Barbara Budrich, Opladen und Farmington Hills.

Neuß, Norbert (2008). Biographisch bedeutsames Lernen. Empirische Studien über Lerngeschichten in der Lehrerbildung. Verlag Barbara Budrich, Opladen and Farmington Hills.

Petrik, Andreas (2007). Von den Schwierigkeiten, politisch zu reden. Konzepte und Praxis einer genetischen Politikdidaktik. Opladen : Verlag Barbara Budrich.

Peukert, Helmut (1998). "Zur Neubestimmung des Bildungsbegriffs," in : Meyer, Meinert A. and Reinartz, Andrea (Eds.) Bildungsgangdidaktik. Denkanstöße für pädagogische Forschung und schulische Praxis. Opladen : Leske + Barbara Budrich, pp. 17-29.

Peukert, Helmut (2000). "Reflexionen über die Zukunft von Bildung." In : Zeitschrift für Pädagogik, 46. 4, pp. 507-524.

Prenzel, Manfred, Gogolin, Ingrid and Krüger, Heinz-Hermann (Eds.) (2007). "Kompetenzdiagnostik," Zeitschrift für Erziehungswissenschaft, special edition 8.

Rorty, Richard (1989): Contingency, Irony, and Solidarity. Cambridge University Press, Cambridge

Rudduck, Jean, and McIntyre, Donald (2007). Improving Learning through Consulting Pupils. London and New York: Routledge.

Ryan, Richard M., Deci, Edward L. (2002). "Overview of Self-Determination Theory: An Organismic Dialectical Perspective," in: Deci, Edward L., and Ryan, Richard M. (Eds.) Handbook of Self-Determination Research. Rochester, N.Y.: The University of Rochester Press, pp. 3-27.

Schenk, Barbara (Ed.) (2005). Bausteine einer Bildungsgangtheorie. Wiesbaden : VS Verlag für Sozialwissenschaften.

Schmidt, Ralf (2004). Schülermitbeteiligung im Fach Geschichte. Martin-Luther-Universität Halle-Wittenberg. (PhD thesis) URL=http://sundoc.bibliothek.uni-halle.de/diss-online/04/04H179/index.htm..

Schulz, Wolfgang (1982). Unterrichtsplanung. München : Urban \& Schwarzenberg.

Straub, Jürgen (1999). Verstehen, Kritik, Anerkennung. Das Eigene und das Fremde in der Erkenntnisbildung interpretativer Wissenschaften. Göttingen : Wallstein Verlag.

Terhart, Ewald (2009). Didaktik. Eine Einführung, Reclam, Stuttgart.

Thomson, Pat, and Gunter, Helen (2006). "From 'consulting pupils' to 'pupils as researchers': a situated case narrative," in: British Educational Research Journal 32. 6, December, pp. 839-856.

Trautmann, Matthias (Ed.) (2004). Entwicklungsaufgaben im Bildungsgang. Wiesbaden : VS Verlag für Sozialwissenschaften. 
Wigotski, Lew [ = Vygotskij, Lew] (2006). Ausgewählte Schriften. Joachim Lompscher (Ed.) vol. 2. International Cultural-historical Human Sciences. Berlin : Lehmanns Media-LOB.de.

Ziegler, Christine (2008). Schülerpartizipation im naturwissenschaftlichen Unterricht, Opladen : Verlag Barbara Budrich. 